\title{
Persistence and protection of the Vulnerable Bengal slow loris Nycticebus bengalensis in Assam and Arunachal Pradesh, north-east India
}

\author{
Nabajit Das, K.A.I. Nekaris, J. Biswas, J. Das and P.C. Bhattacharjee
}

\begin{abstract}
The Bengal slow loris Nycticebus bengalensis is the only strepsirrhine primate in north-east India. It is categorized as Vulnerable on the IUCN Red List. The limited information on its status and ecology is the main hindrance to developing a conservation strategy for this species in India. Therefore during February 2009-May 2010 we surveyed the species in 16 protected areas in Assam and one protected area in Arunachal Pradesh. We used recce transects to estimate encounter rates for the species. A team of 3-4 conducted night-time surveys (18.00-03.00) on foot, covering $370 \mathrm{~km}$ over 99 full and 28 partial nights. We recorded lorises a total of 22 times in nine protected areas in Assam and three times in the protected area in Arunachal Pradesh. The mean distance of lorises from transects at the time of encounter was $15.04 \mathrm{~m}$, at a mean height of $12.36 \mathrm{~m}$ above ground. The encounter rate was $0.06-0.2$ lorises per $\mathrm{km}$, which is relatively low compared to encounter rates for slow lorises elsewhere in their range but higher than recorded by other studies in north-east India. We found that despite hunting and habitat loss Bengal slow lorises still exist in Assam and Arunachal Pradesh, albeit patchily within a forest block. The protected area network in these states is important for their conservation.
\end{abstract}

Keywords Bengal slow loris, distribution, north-east India, Nycticebus bengalensis, protected areas

This paper contains supplementary material that can be found online at http://journals.cambridge.org

\section{Introduction}

$\mathrm{T}$ he Bengal slow loris Nycticebus bengalensis is the only strepsirrhine primate in north-east India. It is categorized as Vulnerable on the IUCN Red List (Streicher et al., 2008). Although five species of slow loris (Bengal slow loris

NABAJIT DAS ${ }^{\star} \dagger$ (Corresponding author), J. BISWAS, J. DAS and P.C. Bhattacharjee $\dagger$ Primate Research Centre NE India, Guwahati-781012, Assam, India. Email nabajit_das1@rediffmail.com

K.A.I. NEKARIS Nocturnal Primate Research Group, Oxford Brookes University, Oxford, UK

${ }^{\star}$ Also at: Nocturnal Primate Research Group, Oxford Brookes University, Oxford, UK

$\dagger$ Also at: Department of Zoology, Gauhati University, Guwahati, Assam, India

Received 27 March 2012. Revision requested 9 May 2012.

Accepted 23 August 2012. First published online 22 July 2014.
Nycticebus bengalensis, greater slow loris Nycticebus coucang, Javan slow loris Nycticebus javanicus, Bornean slow loris Nycticebus menagensis and pygmy slow loris Nycticebus pygmaeus) are considered threatened (Roos, 2003), few field data are available to confirm their conservation status. Several surveys of the Bengal slow loris in north-east India have found this nocturnal primate to be rare or absent despite a well-developed protected area network in north-east India (Radhakrishna et al., 2006). However, nocturnal surveys have been restricted by the presence of armed insurgents and poachers, the presence of species such as elephants Elephas maximus and wild buffalo Bubalus bubalis, and local beliefs about entering the forest at night (Radhakrishna et al., 2006).

Throughout Asia slow lorises are in demand for use in traditional medicine and as pets (Nekaris \& Nijman, 2007). The range of the Bengal slow loris extends from Vietnam to China but in India it is confined to seven north-eastern states (Srivastava \& Mohnot, 2001; BrandonJones et al., 2004). The species is threatened by habitat destruction, hunting (Choudhury, 1992) and the wildlife trade (Radhakrishna et al., 2006) despite being listed in Schedule I of India's 1972 Wildlife Protection Act. The limited information on its status and ecology is the main hindrance to developing a conservation strategy for this species in India. We investigated the status and distribution of the Bengal slow loris, and the threats facing it in protected areas of Assam and Arunachal Pradesh, in north-east India.

\section{Study area}

We conducted a survey of Bengal slow loris in 16 protected areas in north-east India: three National Parks, 10 Wildlife Sanctuaries and two Reserve Forests in Assam and one National Park in Arunachal Pradesh (Fig. 1). This region is characterized by diverse biota and a high level of endemism as it falls on the confluence of the Indo-Malayan and Palearctic biogeographical realms. The region's lowland and moist to wet tropical evergreen forests are the northernmost limit of tropical rainforests (Proctor et al., 1998). The surveyed areas are characterized mainly by evergreen, semievergreen and deciduous forest as a result of their location in the subtropical zone and the prevalence of a monsoonal climate (Champion \& Seth, 1968). 


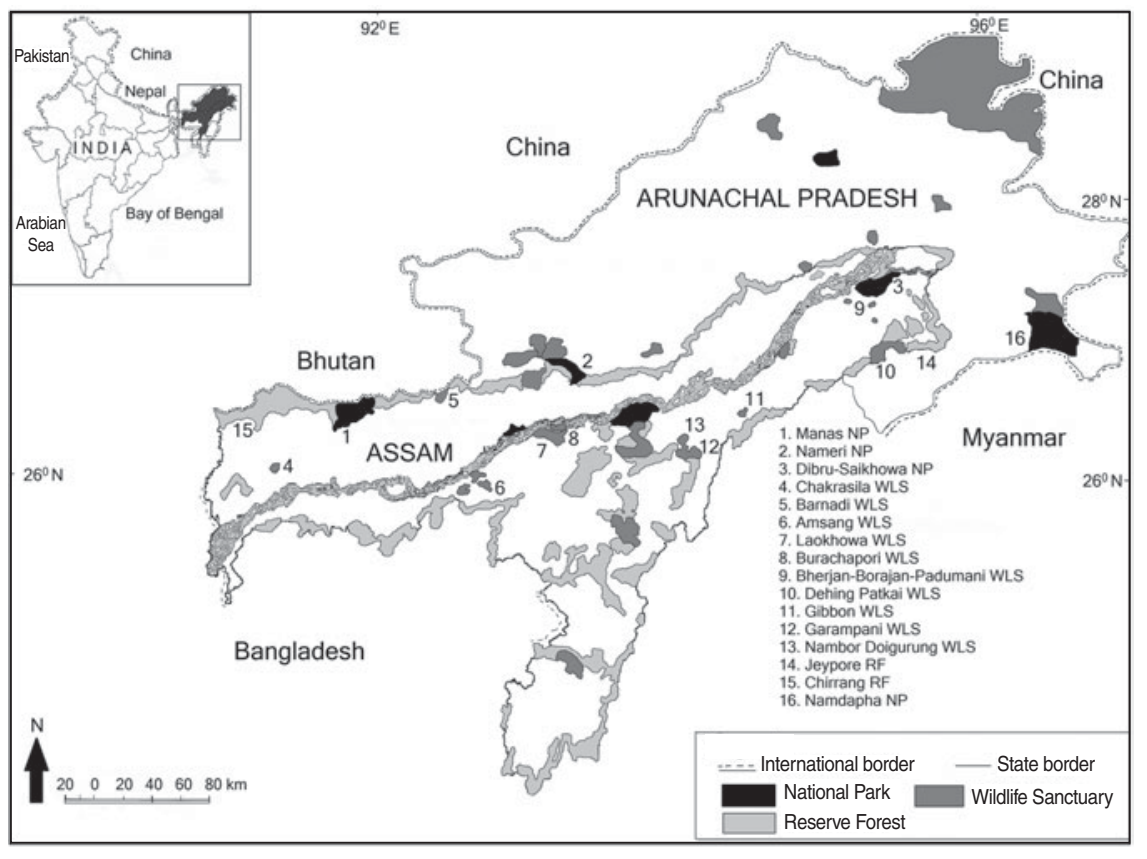

FIG. 1 Locations of the 16 sites where we surveyed for the Bengal slow loris Nycticebus bengalensis in Assam and Arunachal Pradesh, north-east India. The rectangle on the inset shows the location of the main map in India. (NP, National Park; WLS, Wildlife Sanctuary; $\mathrm{RF}$, Reserve Forest).

\section{Methods}

We conducted our survey during February 2009-May 2010. We estimated encounter rates by reconnaissance sampling (Walsh \& White, 1999), using pre-cut paths to maximize access to forested areas over a short period of time (Burnham et al., 1980; Hedges \& Lawson, 2006). We carried out night-time surveys (18.00-22.00 and 22.00-03.00) on foot and, in three instances, by vehicle (where walking at night was prohibited). Each night we selected two transects a minimum of $1 \mathrm{~km}$ apart to avoid counting the same individual more than once, as lorises generally move at $<1 \mathrm{~km}$ per hour (White \& Edwards, 2000; Nekaris, 2003). Transects were $2 \mathrm{~km}$ in length and marked with flagging tape every $50 \mathrm{~m}$. Three to four surveyors walked each transect once, slowly $\left(1 \mathrm{~km} \mathrm{~h}^{-1}\right)$, observing both sides of the transect (Nekaris \& Jayewardene, 2004). We searched all types of vegetation at all heights, using a headlamp to detect the loris's characteristic orange eye-shine.

We used a red filter to observe and confirm the animal, to minimize disturbance (Nekaris, 2003). To facilitate comparisons with other nocturnal primate studies (Singh et al., 2000; Nekaris et al., 2008) we used the number of sightings per $\mathrm{km}$ as an indicator of relative abundance (Sutherland, 2002).

On encountering a loris we recorded its distance from the start of the transect, its perpendicular distance from the transect, the number of individuals, the distance between the animal and the observer, the angle between the animal and the transect line, latitude and longitude, time of detection, the behaviour of the animal when detected (active behaviour: feeding, moving, grooming; inactive behaviour: sleeping, resting, sitting), its height from the ground, the tree species in which it was detected, and the vegetation type. For analysis of loris behaviour we divided observations into three: early night (18.00-21.00), mid night (21.00-24.00) and late night (24.00-03.00). We carried out both full and partial night surveys, where a full night is defined as a session from 18.00-03.00 hours and a partial night is defined as a session of $>4$ hours but less than a whole night, suspended because of heavy rain, elephant attack or fog. We gathered information on habitat and the disturbance caused by poaching, illegal logging, and habitat destruction through extraction of non-timber forest products and crop cultivation, by walking the transects during the day and recording the presence or absence of each of these factors.

We assessed the overall level of threat at each site, on an arbitrary scale of o-very high. We also asked local forest officials, forest guards and local experts, using open questions, if they had encountered lorises.

\section{Results}

During 99 full survey nights and 28 partial survey nights we covered $370 \mathrm{~km}$ of transects within protected areas and reserve forest in Assam and Arunachal Pradesh. We encountered 25 lone Bengal slow lorises, at 10 survey sites. The mean overall encounter rate was in the range $0.06-0.2 \mathrm{~km}^{-1}$. The highest encounter rate $\left(0.2 \mathrm{~km}^{-1}\right)$ was in Namdapha National Park, in Arunachal Pradesh, followed by Gibbon Wildlife Sanctuary $\left(0.18 \mathrm{~km}^{-1}\right)$ and Bherjan Borajan Podumani Wildlife Sanctuary $\left(0.17 \mathrm{~km}^{-1}\right)$ in Assam (Table 1). In Namdapha National Park we encountered three slow lorises during 5 full survey nights covering $15 \mathrm{~km}$ of transects. 
TABLE 1 Data from surveys of Bengal slow loris Nycticebus bengalensis in protected areas of Assam and Arunachal Pradesh (Fig. 1), with survey sites, number of night surveys, total distance covered, number of sightings, number of sightings per km, and any additional information.

\begin{tabular}{|c|c|c|c|c|c|c|c|c|}
\hline Survey sites ${ }^{1}$ & $\begin{array}{l}\text { No. of full } \\
\text { night surveys } \\
(2 \text { transects })\end{array}$ & $\begin{array}{l}\text { No. of partial } \\
\text { night surveys } \\
\text { (1 transect) }\end{array}$ & $\begin{array}{l}\text { Total distance } \\
\text { covered }(\mathrm{km})\end{array}$ & $\begin{array}{l}\text { No. of } \\
\text { sightings }\end{array}$ & $\begin{array}{l}\text { Encounter } \\
\text { rate }\left(\mathrm{km}^{-1}\right)\end{array}$ & Additional information & $\begin{array}{l}\text { Overall level } \\
\text { of threat }^{3}\end{array}$ & Primary threats \\
\hline \multicolumn{9}{|l|}{ Assam } \\
\hline 1. Manas NP & 8 & 3 & 39 & 3 & 0.08 & & ++ & Illegal logging, hunting \\
\hline 2. Nameri NP & 7 & & 21 & 2 & 0.10 & & +++ & $\begin{array}{l}\text { Illegal logging, shifting } \\
\text { cultivation, hunting }\end{array}$ \\
\hline 3. Dibru Saikhowa NP & 6 & & 23.5 & 0 & & $\begin{array}{l}\text { One animal caught in } 2008 \\
\text { and one animal released } \\
\text { by forest rangers in } 2006\end{array}$ & +++ & Flood, hunting \\
\hline 4. Chakrasilla WLS & 6 & 4 & 27 & 0 & & & +++ & Illegal logging \\
\hline 5. Barnadi WLS & 5 & 3 & 23 & 0 & & $\begin{array}{l}\text { Loris body parts confiscated } \\
\text { from poacher }\end{array}$ & +++ & Illegal logging, hunting \\
\hline 6. Amsang WLS & 6 & 1 & 16.5 & 0 & & $\begin{array}{l}\text { Three lorises caught in } \\
2009 \text { and given to } \\
\text { State Zoo, Assam }\end{array}$ & ++ & $\begin{array}{l}\text { NTFP and firewood extraction, } \\
\text { illegal logging }\end{array}$ \\
\hline 7. Laokhowa WLS & 7 & 4 & 31.5 & 0 & & $\begin{array}{l}\text { One loris seen in } 2004 \\
\text { by forest official }\end{array}$ & ++++ & $\begin{array}{l}\text { Extensive NTFP and firewood } \\
\text { extraction, encroachment }\end{array}$ \\
\hline 8. Burachapori WLS & 6 & 3 & 29 & 0 & & & ++++ & $\begin{array}{l}\text { Extensive NTFP and firewood } \\
\text { extraction, encroachment }\end{array}$ \\
\hline $\begin{array}{l}\text { 9. Bherjan Borajan } \\
\text { Podumani WLS }\end{array}$ & 6 & & 18 & 3 & 0.17 & & ++ & Illegal logging \\
\hline 10. Dehing Patkai WLS & 10 & 3 & 34.5 & 3 & 0.09 & & ++ & Illegal logging, hunting \\
\hline 11. Gibbon WLS & 12 & 3 & 38 & 7 & 0.18 & & + & $\begin{array}{l}\text { NTFP and firewood extraction, } \\
\text { small size area, surrounded } \\
\text { by tea garden }\end{array}$ \\
\hline 12. Garampani WLS & 3 & 1 & 10 & 1 & 0.10 & & ++ & Hunting, illegal logging \\
\hline $\begin{array}{l}\text { 13. Nambor-Doigurung } \\
\text { WLS }\end{array}$ & 4 & 2 & 18 & 1 & 0.06 & & + & Road kill, hunting \\
\hline 14. Jeypore RF & 3 & 1 & 11 & 1 & 0.09 & & + & $\begin{array}{l}\text { NTFP extraction, illegal logging, } \\
\text { hunting }\end{array}$ \\
\hline 15. Chirrang RF & 5 & & 15 & 1 & 0.06 & $\begin{array}{l}\text { Westernmost distribution } \\
\text { recorded }\end{array}$ & +++ & $\begin{array}{l}\text { Illegal logging, hunting, NTFP } \\
\text { and firewood extraction }\end{array}$ \\
\hline \multicolumn{9}{|l|}{ Arunachal Pradesh } \\
\hline 16. Namdapha NP & 5 & & 15 & 3 & 0.20 & & + & Hunting, shifting cultivation \\
\hline Total & 99 & 28 & 370 & 25 & 1.13 & & & \\
\hline
\end{tabular}

${ }^{1} \mathrm{NP}$, National Park; WLS, Wildlife Sanctuary; RF, Reserve Forest

${ }^{2}$ All of single loris

${ }^{3}$ Evaluated on arbitrary scale: +, Low; ++, Medium; +++, High; ++++, Very high 
TABLE 2 Encounter rates for the Bengal slow loris in north-east India and South-east Asia, based on nocturnal field surveys, excluding surveys where lorises were not encountered.

\begin{tabular}{lll}
\hline Study site & Encounter rate $\left(\mathrm{km}^{-1}\right)$ & Reference \\
\hline Protected areas in Assam, north-east India & $0.06-0.18$ & This survey \\
Namdapha National Park, Arunachal Pradesh, north-east India & 0.2 & This survey \\
Assam, north-east India & $0.03-0.33$ & Radhakrishna et al. (2006) \\
Meghalaya, north-east India & $0.04-0.10$ & Radhakrishna et al. (2010) \\
Phou Xang He, Central Lao PDR & $0.30-0.65$ & Duckworth (1994) \\
Nakay-Nam Theun, Central Lao PDR & $0.04-0.08$ & Duckworth (1998) \\
Xe Piang, Central Lao PDR & $0.13-0.27$ & Duckworth et al. (1994) \\
Muang Hom, Central Lao PDR & $0.10-0.21$ & Evans et al. (2000) \\
Nam Kading, Central Lao PDR & $0.10-0.22$ & Evans et al. (2000) \\
Nam Ao, Central Lao PDR & $0.14-0.30$ & Evans et al. (2000) \\
Bang Navang, Central Lao PDR & $0.09-0.20$ & Evans et al. (2000) \\
Xe Namoy, southern Lao PDR & $0.40-0.87$ & Evans et al. (2000) \\
Khao Ang Rue Nai Wildlife Sanctuary, eastern Thailand & $0.34-1.02$ & Pliosungnoen et al. (2010) \\
Phnom Kulen National Park, Cambodia & 0.50 & Starr et al. (2010) \\
Samkos Wildlife Sanctuary, Cambodia & $0.38-0.50$ & Coudrat et al. (2011)
\end{tabular}

In Assam we encountered Bengal slow lorises at nine of 15 survey sites (Table 1). No lorises were seen on the transect line. The mean distance of observed lorises from the transect was $15.04 \mathrm{~m}$ (range $3-27 \mathrm{~m}$ ) and the lorises encountered closest to the transect ( 3 and $4 \mathrm{~m}$ ) were in bushes and bamboo thickets.

Lorises were seen at a mean height above ground of $12.36 \mathrm{~m}$ (range $3^{-17} \mathrm{~m}$ ). Poor visibility made it difficult to identify sex and age. The time of night did not have any influence on loris activity, with inactive and active behaviours as likely to occur during any of the three periods $\left(\chi^{2}=1.30, \mathrm{df}=2, \mathrm{P}>0.05\right)$. There was a slightly increasing trend in the number of loris sightings from early to late night $\left(\chi^{2}=1.04, \mathrm{df}=2, \mathrm{P}>0.05\right)$. Lorises commonly fed and travelled in trees of the families Combretaceae and Magnoliaceae, with trees of the genus Terminalia being most commonly used (Supplementary Table $\mathrm{S}_{1}$ ).

Other mammals we encountered during our night surveys included the red giant flying squirrel Petaurista petaurista, the small Indian civet Viverricula indica, the large Indian civet Viverra zibetha, the Asian palm civet Paradoxurus hermaphroditus, the Asian elephant Elephas maximus, the leopard Panthera pardus, the leopard cat Prionailurus bengalensis, the jungle cat Felis chaus, the wild pig Sus scrofa, the Indian hare Lepus nigricollis and the Bengal fox Vulpes bengalensis.

Habitat destruction through anthropogenic activities was a potential threat to the Bengal slow loris and other species at the study sites (Table 1 ). There was evidence of deforestation at all sites. Local people log for both domestic (housing and furniture) and commercial purposes. Hunting is another threat to the loris: its body parts are used in traditional medicine and local people believe that loris meat can increase male power and act as an aphrodisiac.

\section{Discussion}

We present findings about the Bengal slow loris in the westernmost part of its distribution range, confirming its presence in Chirrang Reserve Forest (part of Manas Biosphere Reserve), in Assam. We also confirmed the presence of the Bengal slow loris in protected areas in Assam, including Nameri National Park and Barnadi Wildlife Sanctuary, although mean encounter rates were low. Higher encounter rates $\left(0.20 \mathrm{~km}^{-1}\right)$ in Namdapha National Park and Gibbon Wildlife Sanctuary suggest that these areas may hold substantial populations of lorises and should be targeted as key sites for conservation.

Our findings can be compared with recorded encounter rates for the Bengal slow loris elsewhere in India and South-east Asia (Table 2). Radhakrishna et al. (2006, 2010) found $0.03^{-0.33}$ lorises per $\mathrm{km}$ in parts of Assam and Meghalaya, with a mean of 0.17. Radhakrishna et al. (2006) found slow lorises at only four of 27 sites surveyed in Assam, with similar results from a later study in Meghalaya (Radhakrishna et al., 2010), where they found lorises at two of 16 sites, whereas we detected slow lorises at 10 of our 16 survey sites. The higher encounter rate in our study may be attributable to the methods employed. The number of surveyors has a significant effect on the detectability of this shy animal (Nekaris et al., 2008), with smaller teams recommended. Duckworth (1998) highlighted the inherent difficulties of assessing abundance at night and the importance of detecting animals by their eye shine. We used red lights rather than large search lights as per the previous survey by Radhakrishna et al. (2006). Lorises do not shy away from red lights (Charles-Dominique \& Bearder, 1979), nor do many other nocturnal mammals (Supplementary Table S2). 
We sought slow lorises from dusk until 03.00, after which time animals often dispersed to sleep. Earlier studies (Charles-Dominique \& Bearder, 1979) suggested that nocturnal primates reduce their activity during the middle period of the night. However, our results are in accordance with other work on the genus Nycticebus, suggesting that these animals are active throughout the night, with the exception of periods of torpor (Starr et al., 2010; Coudrat et al., 2011). Bengal slow lorises were most often found in trees of the genus Terminalia (Combretaceae), from which they are known to consume both leaves and gum (Swapna et al., 2009; Rogers \& Nekaris, 2011; Das, pers. obs.), therefore we conclude that this tree genus is important for the conservation of Nycticebus spp.

Considering our findings in Assam and Arunachal Pradesh in the context of recent studies in north-east India we conclude that the persistently low encounter rates for the Bengal slow loris, and the threats to its survival, are consistent with its categorization as Vulnerable on the IUCN Red List. However, this categorization is based only on the threats of habitat loss and hunting. We recommend that a comprehensive survey of Bengal slow loris and other threatened primates be carried out in all seven states of north-east India (Assam, Arunachal Pradesh, Mizoram, Nagaland, Tripura, Manipur and Meghalaya), to inform conservation action in this biodiversity hotspot.

\section{Acknowledgements}

We thank the Department of Environment and Forest of the Governments of Assam and Arunachal Pradesh for permission to carry out the study. We thank the officials at the survey sites who allowed us to study at night, and provided logistical support. This work was supported by the Margot Marsh Biodiversity Foundation, the Rufford Small Grants Foundation, Primate Conservation Inc. and People's Trust for Endangered Species.

\section{References}

Brandon-Jones, D., Eudey, A.A., Geissmann, T., Groves, C.P., Melnick, D.J., Morales, J.C. et al. (2004) Asian primate classification. International Journal of Primatology, 25, 97-164.

Burnham, K.P., Anderson, D.R. \& LaAke, J.L. (1980) Estimate of density from line transect sampling of biological populations. Wildlife Monograph-72. The Wildlife Society, Washington, DC, USA.

Champion, S.H.G. \& Seth, S.K. (1968) Revised Survey of the Forest Types of India. Natraj Publishers, Delhi, India.

Charles-Dominique, P. \& Bearder, S.K. (1979) Field studies of lorisid behavior: methodological aspects. In The Study of Prosimian Behavior (eds G.A. Doyle \& R.D. Martin). Academic Press, New York, USA.

Choudhury, A. (1992) The slow loris (Nycticebus coucang) in Northeast India. Primate Report, 34, 77-83.
Coudrat, C.N.Z., Rogers, L.D. \& NeKaris, K.A.I. (2011) Abundance of primates reveals Samkos Wildlife Sanctuary, Cardamom Mountains, Cambodia as a priority area for conservation. Oryx, 45, 427-434.

Duckworth, J.W. (1994) Field sighting of the pygmy loris (Nycticebus pygmaeus) in Laos. Folia Primatologica, 63, 99-101.

DucKWORTh, J.W. (1998) The difficulty of estimating population densities of nocturnal forest mammals from transect counts of animals. Journal of Zoology, 246, 466-468.

Duckworth, J.W., Timmins, R.J. \& Thewlis, R.C.M. (1994) Field observations of mammals in Laos, 1992-1993. Natural History Bulletin SIAM Society, 42, 177-205.

Evans, T.D., Duckworth, J.W. \& Timmins, R.J. (2000) Field observations of larger mammals in Laos, 1994-1995. Mammalia, $64,55-100$.

Hedges, S. \& Lawson, D. (eds) (2006) Dung Survey Standards for the MIKE Programme. Http://www.cites.org/common/prog/mike/ survey/dung_standards.pdf [accessed 18 September 2008].

Nekaris, K.A.I. (2003) Spacing system of the Mysore slender loris (Loris lydekkerianus lydekkerianus). American Journal of Physical Anthropology, 121, 86-96.

Nekaris, K.A.I., Blackham, G. \& Nijman, V. (2008) Conservation implications of low encounter rates of five nocturnal primate species (Nycticebus sp.) in Southeast Asia. Biodiversity Conservation, 17, 733-747.

Nekaris, K.A.I. \& Jayewardene, J. (2004) Survey of the slender loris (Primates, Lorisidae Gray, 1821; Loris tardigradus Linnaeus, 1758 and Loris lydekkerianus Cabrera, 1908) in Sri Lanka. Journal of Zoology, 262, 327-338.

NeKARIS, K.A.I. \& NiJMAn, V. (2007) CITES proposal highlights rarity of Asian nocturnal primates (Lorisidae: Nycticebus). Folia Primatologica, 78, 211-214.

Pliosungnoen, M., Gale, G. \& Savini, T. (2010) Density and microhabitat use of Bengal slow loris in primary forest and non-native plantation forest. American Journal of Primatology, 72, $1108-1117$.

Proctor, J., Haridasan, K. \& Smith, G. (1998) How far north does lowland evergreen tropical rain forest go? Global Ecology and Biogeography Letters, 7, 141-146.

Radhakrishna, S., Datta-Roy, A., Swapna, N. \& Sinha, A. (2010) Population survey of the Bengal slow loris, Nycticebus bengalensis, in Meghalaya, Northeast India. Primate Conservation, $25,105-110$

Radhakrishna, S., Goswami, B.A. \& Sinha, A. (2006) Distribution and conservation of Nycticebus bengalensis in northeastern India. International Journal of Primatology, 27, 971-982.

Rogers, L.D. \& NEKARIS, K.A.I. (2011) Behaviour and habitat use of the Bengal slow loris Nycticebus bengalensis in the dry dipterocarp forests of Phnom Samkos Wildlife Sanctuary, Cambodia. Cambodian Journal of Natural History, 2, 92-103.

Roos, C. (2003) Molecular phylogeny of prosimians, langurs and gibbons. PhD thesis. Lehrstuhl fur Genetik, Wissenschaftszentrum Weihenstephan fur Ernahrung, Landnutzung und Umwelt, Technical University, Munich, Germany.

Singh, M., Anand Kumar, M., Kumara, H.N. \& Mohnot, S.M. (2000) Distribution and conservation of slender lorises (Loristardigradus lydekkerianus) in southern Andhra Pradesh, South India. International Journal of Primatology, 21, 721-730.

Srivastava, A. \& Mohnot, S. (2001) Distribution, conservation status and priorities for primates in Northeast India. ENVIS Bulletin: Wildife and Protected Areas: Non-Human Primates of India, 1, 102-108.

Starr, C., Nekaris, K.A.I., Streicher, U. \& Leung, L. (2010) Traditional use of slow lorises Nycticebus bengalensis and 
N. pygmaeusin Cambodia: an impediment to their conservation. Endangered Species Research, 12, 17-23.

Streicher, U., Singh, M., Timmins, R.J. \& Brockelman, W. (2008) Nycticebus bengalensis. In IUCN Red List of Threatened Species v. 2013.1. Http://www.iucnredlist.org [accessed 15 October 2011].

Sutherland, W.J. (2002) Mammals. In Ecological Census Techniques (ed.W.J. Sutherland), pp. 260-278. Cambridge University Press, Cambridge, UK.

Swapna, N., Radhakrishna, S., Gupta, A.K. \& Kumar, A. (2009) Exudativory in the Bengal slow loris (Nycticebus bengalensis) in Trishna Wildlife Sanctuary, Tripura, Northeast India. American Journal of Primatology, 71, 1-9.

Walsh, P.D. \& White, L.J.T. (1999) What it will take to monitor forest elephant populations. Conservation Biology, 13, 1194-1202.

White, L. \& Edwards, A. (2000) Methods for assessing the status of animal populations. In Conservation Research in the African Rain Forests: A Technical Handbook (eds L. White \& A. Edwards). Wildlife Conservation Society, New York, USA.

\section{Biographical sketches}

NABAJIT DAS is interested in the conservation of non-human primates in north-east India. His research currently focuses on the ecology and conservation of the Bengal slow loris. K.A.I. NEKARIS has studied Asian lorises for over 20 years and conducted field studies of all recognized taxa of slow and slender lorises in South and Southeast Asia. She has also initiated awareness and capacity-building programmes for loris conservation in several countries. J. B Is W As has extensive field experience in primate conservation and has studied non-human primates in the forests of north-east India, particularly in Assam and Arunachal Pradesh. He is especially interested in conservation of the western hoolock gibbon in north-east India. J. D A S is a large-mammal conservationist in north-east India, with extensive experience of surveying non-human primates in the region. P.C. BHAtTACHARJeE is an ecologist and pioneering conservation biologist in north-east India. He led the Indo-US Primate Project until its conclusion in 2000 . 